\title{
Open innovation and firms' performance: state of the art and empirical evidences from the bio-pharmaceutical industry
}

\section{Erica Mazzola*, Manfredi Bruccoleri and Giovanni Perrone}

\author{
Università degli Studi di Palermo, \\ Viale delle Scienze, ED 8, \\ 90128 - Palermo, Italy \\ Email: erica.mazzola@unipa.it \\ Email: manfredi.bruccoleri@unipa.it \\ Email: giovanni.perrone@unipa.it \\ *Corresponding author
}

\begin{abstract}
The research presented in this paper explores the effect of inbound, outbound and coupled open innovation practices on firms' performances in the biopharmaceutical industry. Specifically, although existing researches on open innovation effectiveness have separately investigated the effect of open innovation practices on innovation and financial performance, this study evaluates the concurrent effect of these practices on both such performance dimensions in a single framework. We state the importance for a manager to explore concurrently the influence of specific open innovation practices both on innovation and economic-financial performance. We empirically test our framework on a sample of 120 companies listed on the NASDAQ biotechnology index.
\end{abstract}

Keywords: inbound open innovation practices; outbound open innovation practices; coupled open innovation practices; innovation performance; economic-financial performance; biopharmaceutical industry; NASDAQ.

Reference to this paper should be made as follows: Mazzola, E., Bruccoleri, M. and Perrone, G. (2016) 'Open innovation and firms' performance: state of the art and empirical evidences from the bio-pharmaceutical industry', Int. J. Technology Management, Vol. 70, Nos. 2/3, pp.109-134.

Biographical notes: Erica Mazzola received her Doctoral in Industrial Engineering from the University of Palermo in 2010. In 2010, she was a Visiting Scholar at London Business School. Since January 2011 to now, she has a Postdoctoral fellowship at University of Palermo. Her current research interests include open innovation, crowdsourcing, social capital and social network analysis. Her other research interests include strategic alliances, particularly the firms' strategic use of inter-firm relationships and the process of strategic alliance' formation. Amongst others, she published in the journals International Journal of Production Economics, Technology Analysis \& Strategic Management, and International Journal of Innovation Management.

Manfredi Bruccoleri is an Associate Professor of Operations Management and Business Process Management and teaches for bachelor and master students of the University of Palermo. He holds a Doctoral in Production Engineering and 
in 2001 he was Visiting Scholar at the School of Engineering of the University of Michigan (Ann Arbor). He collaborates with companies from different manufacturing and service industries for both teaching and research projects. $\mathrm{He}$ coordinated several business process reengineering projects in different Italian companies but also in several public administration offices. His research interests focus on operations management, behavioural operations, supply chain management, reverse logistics, business process management, networking strategy and open innovation. He is author and co-author of about 80 research papers published in international journals and conference proceedings.

Giovanni Perrone is a Full Professor of Business and Management Engineering at the University of Palermo. He is member of the board of the AiIG (Italian Association of Engineering Management), member of the board of EurOMA, member of the PNICube (The Association of Italian Incubator), member of the Spin-off Commission of the University of Palermo and Coordinator of the Start Cup Competition at the University of Palermo. He was a Director of the Engineering Management degree programme at the University of Palermo from 2005-2011 and member of the board of the Business Incubator of the University of Palermo from 2008 to 2011 . He was a Visiting Scholar at MIT (Cambridge, USA) in 1993, Visiting Scientist at Aachen Technical University in 1994 and Visiting Professor at North Carolina State University in 1996-97. His scientific activity is focused on operations and innovation management. He is co-author of about 130 publications mainly within international journals and conference proceedings.

\section{Introduction}

Open innovation (OI), a term promoted by Chesbrough in his book of 2003, describes how companies have shifted from so-called 'closed innovation' processes towards a more open way of innovating. In recent years scholarly interest in the relationship between OI and firm performance has increased (Gassmann et al., 2010; Mazzola et al., 2012; Spithoven, 2013). The question of how openness influences the capacity of firms to innovate and the ability to obtain higher economic returns is one of the main issues of OI research, as well as of this paper. Following the conceptualisation of Chesbrough (2003), researchers differentiate between three processes of OI: inbound, outbound and coupled. Inbound process refers to the purposive inflows of knowledge and regards the technology exploration and innovation activities to capture and benefit from external sources of knowledge. Inbound process can be implemented by adopting so-called OI inbound practices such as in-licensing, research institution collaborations, purchasing of scientific services, etc. Outbound process concerns the establishment of relationships with external partners with the purpose of bringing ideas to market faster than by internal development. The outbound process can be implemented by adopting so-called OI outbound practices such as out-licensing, spin-off, supply of scientific services, etc. Finally, coupled process refers to co-innovation with complementary partners through structured cooperation such as alliances and joint ventures. In the coupled process companies combine the inbound 
process, to gain external knowledge, with the outbound process, to bring ideas to market and, in doing so, jointly develop and commercialise innovation. Coupled process can be implemented by adopting so-called OI coupled practices such as co-patenting, strategic alliances, etc. A few years after the concept of OI was introduced, researchers started looking for empirical evidences validating the effectiveness of OI processes. This paper aims at contributing to this stream of research. Specifically, we identify two points of weakness within the state of the art and we will try to fill these gaps.

First, most of the previous literature investigates the effect of inbound, outbound, and coupled innovation practices separately with respect to different dimensions of performance. Some researches bring evidences of the positive impact of specific OI practices on innovation performance; others, conversely, demonstrate the negative impact on innovation performance. The same can be said for the impact of such OI practices on financial performance. Not considering the concurrent effect of a given OI practice on both financial and innovation performance would not actually help managers in making the right decision about what portfolio of OI practices to adopt. For this reason, the first research objective of this paper is to make a contribution in this direction by investigating the concurrent effect of OI practices on both performance dimensions, economic-financial and innovation.

Second, most of the literature investigates the effect of different levels of OI adoption on performance (e.g. the open innovation breadth and depth). Several authors consider both the number/type of partners with which the company collaborates and the number/type of phases of the innovation process that the company opens to external contributions; this determines the degree of openness of a company (Laursen and Salter, 2006; Lazzarotti and Manzini, 2009). This is not actually helpful for the manager who has to select the right OI practice (or set of practices) to better achieve specific objectives. Motivated by this consideration, the second research objective of this paper is to explore the impact of single and specific OI practices on performance, instead of just the degree of openness.

Summing up, this paper, by achieving the two above-mentioned goals, provides some important managerial implications because it contributes to a better understanding of how a mix of practices, which opens the company R\&D process beyond its boundaries might influence at the same time and in different ways the innovation outcomes and the economic-financial returns.

The context of this study is the biopharmaceutical industry; the data are based on 120 companies listed in the NASDAQ biotechnology index (NBI). We found few contributions in OI literature that explain the adoption of OI practices in the biopharmaceutical industry (Bianchi et al., 2011). Despite this little attention, we argue that the biopharmaceutical industry, because of its uniqueness, may offer important intuitions to analyse the effects of the OI practices on firm performance.

The rest of the paper is structured as follows. After the literature analysis and the research motivations, we develop the theoretical framework in Section 3. Sections 4 and 5 respectively present the research methods and results of the empirical analysis. Theoretical and managerial implications are discussed in Section 6, while conclusions and opportunities for further researches are reported in the final section. 


\section{Literature review}

Through a systemic literature review of empirical studies published between 2003 and 2014, we examine 60 scientific papers that empirically investigate the role of the OI processes in explaining innovation and financial performance. For the purposes of our research, we categorise and summarise in Table 1 these papers according to two criteria: typology of performance and OI processes.

\subsection{Criterion 1: typology of performance}

We find 42 papers dealing exclusively with the effect of OI processes on innovation performance and 14 papers dealing exclusively with economic-financial performance. In our review, we find only four papers dealing with the effect of OI practices on both kinds of performance. Such papers are underlined in Table 1. However, they adopt aggregate measures for OI adoption, and they only focus mainly on the inbound process. The paper by Spithoven et al. (2010) investigates the impact of two aggregate constructs that measure the level of inbound OI adoption that are 'inter-firm linkages' and 'inter-organisational linkages'. Similarly, Hwang and Lee (2010) investigate the influence of the breadth and the depth of the external knowledge sources: the breadth of the external technology sources, a concept introduced by Laursen and Salter (2006), is computed as the sum of 13 external sources, i.e. inbound practices. The same can be said for the depth, that is the weighted sum of the same practices by their importance. Gronum et al. (2012) evaluate the collaboration activities of the firms as an aggregate measure by considering the number of network ties engaged by nine different actors. Specifically, based on longitudinal data from 1,435 small and medium enterprises, the authors show a positive relation between collaboration activities and economic performance and collaboration activities and innovation performance. Recently, Cheng and Huizingh (2014), in a survey of 223 Asian service firms, developed and tested a comprehensive measurement scale for OI that captures in one measure the entire range of OI activities, including inbound, outbound, and coupled activities. Their final measure of OI comprises ten items and indicates to what extent a firm has implemented these three open innovation activities. Their results indicate that performing OI activities is positively related to several dimensions of innovation and financial performance: new product/service innovativeness, new product/service success, customer performance, and financial performance.

\subsection{Criterion 2: OI processes}

Following the considerations of Chesbrough (2003) and Gassmann and Enkel (2004) we group these 60 papers into the three basic OI processes: inbound, outbound and coupled. Most of the scholars investigate in depth the effect of practices belonging to the inbound process on firm performance. In literature, the effect of outbound and coupled processes on performance is definitively less investigated. Moreover, we notice that, as in Criterion 1, the majority of the empirical works investigate the impact of OI practices on performance by testing the effect of aggregate measures of OI adoption level. For example, in the study of Kang and Kang (2009), the extent of using R\&D collaborations is measured by managers' perceptions of the total contribution coming from ten different collaboration partners. Hung and Chiang (2010), to assess the company's inclination to 
utilise external ideas and profit from their innovation, develop a multi-item construct named 'OI proclivity'. There are just a few papers that test the impact of a specific OI practice on a specific performance measure. However, these papers do not explore the concurrent effect of specific OI practice on both financial and innovation performance. For example, Wadhwa and Kotha (2006) study the link between the specific practice of making corporate venture capital investments and innovation outcomes. Similarly, Tsai (2009) examines the relationships between different types of collaborations with different partners (suppliers, customers, competitors, and universities) and product innovation performance. Three main findings emerge from the analysis of literature on OI and performance. First, researches mainly focus on investigating the effect of inbound process on firm performance, while disregarding the effect of outbound and coupled processes (with few exceptions). Second, most researches deal with aggregate measures of OI practices and do not consider the effect of a specific practice on performance. Third, with very few exceptions, researches do not consider in their analysis innovation and economic-financial performance dimensions concurrently. This paper aims at filling these gaps in the OI literature and provides interesting theoretical and managerial suggestions.

Table 1 Literature analysis on OI and firm performance

\begin{tabular}{|c|c|c|c|c|}
\hline & & \multicolumn{3}{|c|}{ Criterion 1} \\
\hline & & Inbound & Outbound & Coupled \\
\hline \multirow{20}{*}{ 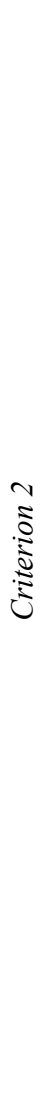 } & \multirow{20}{*}{ 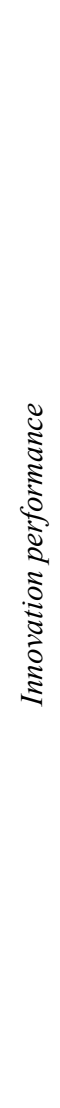 } & Chang et al. (2012) & Cheng and Huizingh (2014) & Cheng and Huizingh (2014) \\
\hline & & Cheng and Huizingh (2014) & $\begin{array}{l}\text { Inauen and } \\
\text { Schenker-Wicki (2012) }\end{array}$ & Faems et al. (2005) \\
\hline & & Chiang and Hung (2010) & & Fey and Birkinshaw (2005) \\
\hline & & Ebersberger et al. (2012) & & Lin et al. (2012) \\
\hline & & Fey and Birkinshaw (2005) & & Love and Mansury (2007) \\
\hline & & Foss et al. (2011) & & Neyens et al. (2010) \\
\hline & & Grimpe and Kaiser (2010) & & $\begin{array}{l}\text { Nieto and } \\
\text { Santamaria (2007) }\end{array}$ \\
\hline & & $\underline{\text { Gronum et al. (2012) }}$ & & Suh and Kim (2012) \\
\hline & & Huang and Rice (2009) & & Vega-Jurado et al. (2009) \\
\hline & & Hwang and Lee (2010) & & \\
\hline & & $\begin{array}{l}\text { Inauen and } \\
\text { Schenker-Wicki (2011) }\end{array}$ & & \\
\hline & & Kang and Kang (2009) & & \\
\hline & & Kim and Park (2010) & & \\
\hline & & Lasagni (2012) & & \\
\hline & & Laursen and Salter (2006) & & \\
\hline & & Li and Tang (2010) & & \\
\hline & & Love and Mansury (2007) & & \\
\hline & & Love et al. (2013) & & \\
\hline & & $\begin{array}{l}\text { Mention and } \\
\text { Asikainen (2012) }\end{array}$ & & \\
\hline & & Nieto and Rodriguez (2011) & & \\
\hline
\end{tabular}


Table 1 Literature analysis on OI and firm performance (continued)

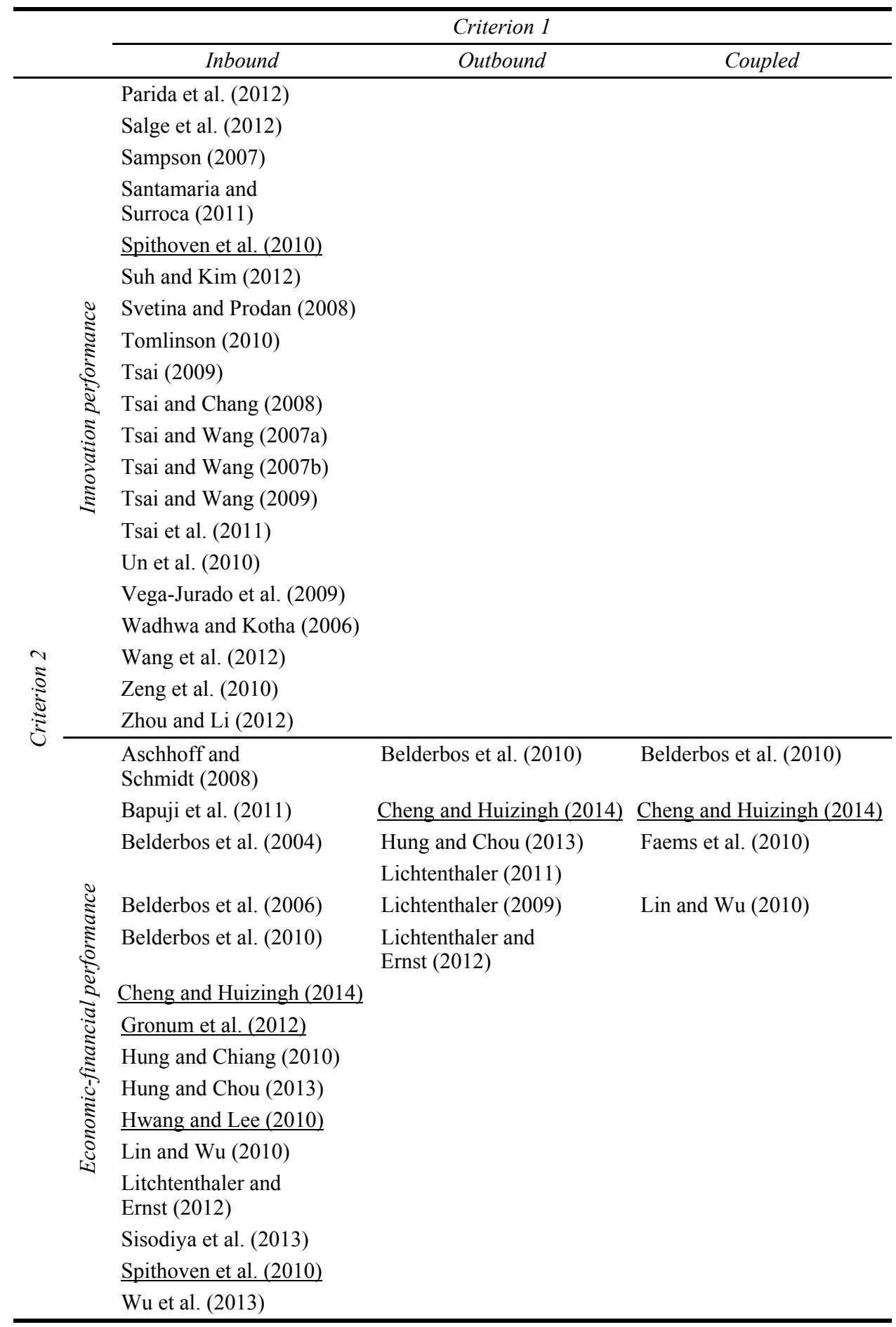




\section{Hypotheses development}

\subsection{Hypothesis on inbound OI}

Prior research suggests that a firm can advance its innovation performance by interacting with different partners, primarily including suppliers, customers, competitors, and research organisations (Hung and Chiang, 2010; Laursen and Salter, 2006). For example, several scholars find confirmation that collaboration with suppliers is beneficial for a firm's innovation because of the combination of complementary capabilities and the common goals between firm and suppliers (Hwang and Lee, 2010; Tsai, 2009). Laursen and Salter (2006) find that innovation performance increases with both the breadth and depth of external search, i.e. with the diversity of external information sources, such as suppliers and customers and their intensity of use. Moreover, several scholars find that collaboration with research institutes and universities positively affect product innovation performance (Hung and Chiang, 2010; Tsai, 2009); indeed, universities and research institutes have systems and mechanisms that facilitate access to new and complex knowledge. Along with the positive effect of inbound OI on the innovativeness of the firm, much research has claimed that the role of external acquisition of knowledge has a negative effect on the innovation output of firms (Inauen and Schenker-Wicki, 2011). There may be multifaceted reasons behind this negative relationship, including the inadequate or insufficient absorptive capacity (Cohen and Levinthal, 1990) of firms to absorb knowledge and technologies emerging in other industries, or the drainage of resources that the acquisition of external knowledge creates.

Besides impacting on innovation performance, some empirical works (Aschhoff and Schmidt, 2008; Gronum et al., 2012) show that collaboration with external partners tends to be beneficial for the firm, not only in terms of innovation, but also in terms of financial performance. For instance, Inauen and Schenker-Wicki (2011) reveal that openness towards universities in R\&D processes has a positive impact on the percentage of innovative product sales over total sales. In addition to the positive effect of inbound OI on financial outcomes, researchers such as Belderbos et al. (2010) suggest the possibility of a negative effect of these practices on financial performance. Indeed, although collaborative R\&D activities might reduce technical risks and costs, engaging in R\&D collaborations with external partners might introduce relational risks and increase coordination costs (Das and Teng, 1998). To mitigate such risks companies require time-consuming contract negotiations or the implementation of costly monitoring mechanisms. Moreover, because of the presence of cultural and organizational differences among different partners it may be necessary to make relational investments in order to facilitate coordination.

Following such considerations, we expect a significant and concurrent effect of inbound OI practices on both innovation and economic-financial performance. However, we aim at investigating such effect, practice by practice, and do not consider aggregate measures of inbound OI adoption level. For this reason, we state the first hypothesis of the model.

Hypothesis $1 \quad$ A given inbound open innovation practice significantly and concurrently influences both innovation and economic-financial performance. 


\subsection{Hypothesis on outbound OI}

The process of outbound OI has being increasingly considered as a strategic activity by firms, who can profit from their own innovations without investing in complementary assets. Through various contractual forms (e.g. out-licensing agreements, spin-offs, or technology sales) firms try to externally leverage their technological knowledge to generate additional revenues (Lichtenthaler and Ernst, 2007). Prior empirical studies on the outbound OI process focus on the effects of these activities on financial performance (Lichtenthaler, 2009; Belderbos et al., 2010). Lichtenthaler (2009) addresses the relationship between outbound open R\&D strategies, licensing-out among others, and firm performance; by using data from 136 industrial firms, his results show that a positive relationship exists between outbound strategies and firm financial outcomes. Apart from licensing-out, any knowledge asset may be divested through a spin-off, and this increases the financial outcomes of the firm (Chiaroni et al., 2010). Where patents are ineffective or technology does not match with the strategic core business, companies can develop policies to finance or found their tacit knowledge and thus actively participate in the success of their spillovers (Lichtenthaler and Ernst, 2007). Along with the positive effect, outbound OI arrangements may also have a negative effect on financial performance (Lichtenthaler, 2011). By transferring to external competitors valuable and competitively relevant technological knowledge, the firm's relative technological position may deteriorate through the increase of competition in its own market. As a result, this increase of competition may lead to profit dissipation effects in a firm's business segment. These negative effects may outweigh the positive financial effect of generating licensing revenues, so that the overall effect of outbound OI practices could become negative on firm performance.

While monetary compensation is the main objective in a vast majority of external technology commercialisation, non-monetary incentives also guide a firm to open its boundaries. The commonly acknowledged non-monetary objective for external knowledge exploitation is gaining access to another company's technology portfolio (Lichtenthaler, 2009). Here, the aim is to engage in cross-licensing agreements for applying external exploitation efforts to forward external acquisition efforts. While outbound process of external knowledge provides great financial opportunities, there is also the risk of negative effects on innovation performance. Managers that decide to license out their Intellectual Property or divesting knowledge assets certainly increase short short-term profits, thus meeting analysts' expectations and stakeholders' pressure, but, on a long-range horizon, may negatively affect a firm's internal innovation process (Lichtenthaler, 2009). From a long-term perspective these practices may weaken the specific R\&D capabilities of a firm, leading to a lower innovation performance.

Following such considerations, we expect a significant and concurrent effect of outbound OI practices on both innovation and economic-financial performance. Again, we aim at investigating such an effect practice by practice and do not consider aggregate measures of outbound OI adoption level. For this reason, we state the second hypothesis of the model.

Hypothesis 2 A given outbound open innovation practice significantly and concurrently influences both innovation and economic-financial performance. 


\subsection{Hypothesis on coupled OI}

Coupled process refers to co-innovation with complementary partners through structured inter-firm relationships such as alliances and joint ventures. R\&D inter-organisational collaborations enable firms to scan their environment for new windows of opportunity and technologies. A significant number of scholars investigate the relationship between R\&D inter-firm collaborations and firm innovation outcomes, showing how technological collaborative networks, R\&D and manufacturing alliances among others, are of crucial importance in achieving a higher degree of novelty in product innovation (Faems et al., 2005; Love and Mansury, 2007). Collaborative patents (co-patents) are defined as patents with more than one assignee. Co-patents are useful indicators of coupled OI practices since they reflect a fraction of the inter-firm's collaborative relationships (Lin et al., 2012). The co-patenting processes ask for collaboration lasting throughout the whole innovation process, exploration and exploitation, until the utilisation of the invented technology toward the market. By developing co-patents, companies improve both innovative and financial performance since they reduce costs and lead times of new patent development, enhancing the technological quality and market adaptability of innovation outputs. Besides positively impacting on innovation performance, inter-firm collaborations also negatively affect the efficiency of a firm's innovation performance. With a sample of 2,456 alliances formed from 143 biopharmaceutical firms, George et al. (2001) find that vertical alliances are negatively related to the number of developed patents.

Although R\&D inter-organisational collaborations might increase financial outcomes, they introduce relational risks, due to opportunistic behaviours, and increase coordination costs needed to implement monitoring mechanisms (Faems et al., 2005). Based on a study of 68 R\&D-intensive firms, Belderbos et al. (2010) suggest that the potential advantages of strategic alliances for technological activities might not compensate for the potential disadvantages, such as the incurred increase in coordination costs. In contrast to inbound OI processes, coupled processes imply that the company also needs to share the rewards with its collaborating partners.

Thus, the collaboration might increase the probability of generating new ideas, successfully raising innovation and financial performance, but at the same time it might substantially limit the ability of the firm to appropriate the value of such activities.

Following such considerations, we expect a significant and concurrent effect of coupled OI practices on both innovation and economic-financial performance and we state the third hypothesis of the model.

Hypothesis 3 A given coupled open innovation practice significantly and concurrently influences both innovation and economic-financial performance.

\section{Method}

\subsection{Sample and data collection}

The hypotheses describing the influence of OI practices on both innovation and economic-financial performance are tested on a sample of biopharmaceutical companies listed on the NASDAQ stock market, specifically the NBI subset. Despite a limited 
number of OI researches into the biopharmaceutical industry, this industry is an early pioneer of OI (Bianchi et al., 2011; Chiaroni et al., 2007). In recent decades the biopharmaceutical industry has been faced with many challenges that have changed how to organise companies' innovation activities. First of all, while a typical R\&D process extends up to 13 years, only one out of 10,000 molecules becomes a product suitable for the market (Bianchi et al., 2011). Second, markets for pharmaceutical products tend to become more fragmented, leading to an increased risk of market failure. In addition, the number of new drug approvals is constantly declining, while R\&D expenditures are increasing due to the high investments in new drug discovery technologies and more complex clinical studies. As a response to these challenges, biopharmaceutical firms have started to rethink their innovation activities, focusing on new modes to organise the R\&D processes that go beyond their firm's boundaries. Thus, these features make NBI companies an appropriate target for the study of the impact of OI practices on firm performance.

We consider cross-sectional data of 128 NBI firms, registered on the NASDAQ from 2001 to 2010. We gather data from the public annual reports of NBI companies. Specifically, since several researches (Nadkarni and Narayanan, 2007) have revealed that the $10-\mathrm{K}$ model is a much more complete source of information for management research than the annual report, we collect the 10-K form of NBI firms' annual reports. Moreover, the $10-\mathrm{K}$ form is an appropriate source of information for our kind of analysis since it allows us to collect both financial and innovation data. We remove eight biopharmaceutical companies from the initial sample of 128 NBI companies, since they have missing data on their $10-\mathrm{K}$ form. Therefore, we conduct the analysis on a sample of 120 companies.

\subsection{Dependent variables}

In the innovation management literature, we find a long history of conflict within the theme of measuring firms' innovation performance. Scholars have employed several kinds of measures to capture firms' innovative performance (Hagedoorn and Cloodt, 2003), such as R\&D inputs, patent counts, patent citations, counts of new product introductions, or more specific survey-based measurements (Ahuja, 2000; Bae and Gargiulo, 2004; Soh, 2003). Our choice to measure the firm's innovation outcome as the total number of patents developed by the firm throughout $2001-2010$ is basically due to the following rationales.

First, patent-based measures provide a relatively fair measure of new knowledge. Indeed, by definition patents are required to describe something novel and not obvious; an invention, to be patented, must be something not already known from prior knowledge (Walker, 1995). Thus, patents provide a good measure of technologically new knowledge that is the core concept of OI research.

Second, several studies have used patents as a measure of innovation performance (Ahuja, 2000; Gilsing et al., 2008; Padula, 2008; Phelps, 2010; Salman and Saives, 2005; Schilling and Phelps, 2007; Vanhaverbeke et al., 2009). Thus, following this long history in innovation management literature we use the number of patents as a proxy of the firm's innovation performance.

Third, since the importance of patenting differs greatly across industries, a further rationale underlying our choice is the research context we select to test our hypotheses. Indeed, our hypotheses are tested on a sample of 120 biopharmaceutical companies listed 
on the NASDAQ stock market, specifically the NBI subset. It is well known that biopharmaceutical firms are more specialised in patent development and commercialisation then pursuing the entire innovation path from early discovery to product development (Rothaermel and Deeds, 2004).

Fourth, the availability of patent data motivates the use of a patent-based measure of innovation in this study. Indeed, electronic access to patent data through the US Patent and Trademark Office databases has increased the use of patents in industrial and academic research (Walker, 1995).

We operationalise the innovation performance variable considering the total number of patents (Patents) developed by the firm throughout 2001-2010. To construct the patent measure, we use patent data from the U.S. Patents and Trademarks Office (USPTO), which is a comprehensive and publicly available database of US patents. Following the same considerations as Lin et al. (2012), we gather data on patents obtained in the USA, since this represents the largest market for the biopharmaceutical industry, and thus companies generally patent there before in any other countries.

In more detail, we operationalise the patent variable by using a simple patent count as a measure of innovation outcome. We made this choice, which is in contrast to some scientific literature that suggests using patent citation instead of patent count, for several reasons. Indeed, even if innovation performance is better captured by patent citations, we believe that citations are accumulated with age and therefore this measure might be biased towards old patents. More specifically, in the case of the biopharmaceutical industry, because the companies are mostly young (as are their patents), the number of patent citations would not be a good measure for innovation performance. Also, companies tend to have different policies toward the patenting issue, due to the estimated costs for issuing patents. For instance, for a pharmaceutical company such as Roche these costs must be insignificant, while for a small biotechnology firm, such as Acadia, this expenditure could represent a significant investment. For these reasons, in this particular industry, we believe that patent counts adequately capture the innovation performance of biopharmaceutical companies.

With regard to the financial implications of OI practices, accounting measures are typically used in literature as indicators of performance; for example, Lichtenthaler (2009) uses a financial indicator of profitability, i.e. return on sales. We analyse the effects of OI practices on economic-financial performance by adopting a common measure of profitability, i.e. the revenue. In particular, following previous works on OI and performance (Spithoven et al., 2010), we measure the growth of the firm's revenue (Growth of revenue) from 2001 to 2010. Recent literature recognises revenue growth as a more direct measure of firm competitiveness together with income growth and profit margin, rather than financial variables, such as stock valuation (Lee, 2006). Moreover, in his work, Ferrary (2011) adopts the company's revenue as a proxy for activities of exploitation of new knowledge. It is possible to assert that the choice of revenue is consistent with our conceptual framework since revenue growth reflects the firm's capability to convert its new knowledge into exploitable innovations.

Moreover, even if the data we collect for the revenue growth are from 2001 to 2010 and thus include the years of the economic crisis of 2009, this is not an issue. Indeed, cyclical factors, such as the economic crisis of 2009, which may affect companies' financial performance, are spread over all firms in the sample, so it is possible to consider their overall effect as null. Since we select all the companies listed on the NBI, the possible differences due to the economic crisis are annulled within the sample. 


\subsection{Independent and control variables}

As regards the independent variables, we consider several practices as inbound, outbound and coupled OI-oriented by basically reviewing the most relevant literature on OI that has already associated each of these practices to the inbound, outbound and coupled categories. Besides self-explanatory OI practices such as licensing agreements, co-patenting, purchase and supply of technical and scientific services (Bianchi et al., 2011), we also identify and name two practices 'Platform biotech firms' and 'Institutional collaboration' by using the name of the 'collaborator' instead of the agreement because we observed a large amount of OI practices of the 'inbound' kind with these types of collaborators. So, for example, we also count and collect the number of Platform biotech companies the firm collaborates with for knowledge inflow.

Moreover, we also consider the inbound OI practice 'Venture capital', which the traditional literature has considered as a source to acquire financial resources. We include this practice within the category of inbound following the considerations of several authors that advance the idea that venture capitals are likely to be a source of knowledge and highly valuable innovative ideas rather than just a source of financial resources (Benson and Ziedonis, 2009; Dushnitsky and Lenox, 2005; Ferrary, 2011; Wadhwa and Kotha, 2007). For example, Dushnitsky and Lenox (2005) suggest how venture capital programmes are important instruments for accessing external valuable knowledge (inflow of knowledge - inbound) that increases firm innovation rates. Thus, following these considerations, we include venture capital within the inbound category.

We report in Table 2 the 14 OI practices (six inbound, five outbound, and three coupled) identified in our research, together with the name of the authors that investigated them in previous papers. Also, in Table 2 we report the measures we use for operationalising them and the short names (Variable) we use in the following statistical analysis. We derive information about how many times each company was involved in each OI practice from its 10-K forms for 2001-2010.

Table 2 OI practices, literature, variable names and constructs

\begin{tabular}{|c|c|c|c|}
\hline OI practices & Literature & Variables & $\begin{array}{c}\text { Measurements } \\
\text { (for the period 2001-2010) }\end{array}$ \\
\hline \multicolumn{4}{|c|}{ Inbound practices } \\
\hline \multirow[t]{2}{*}{ In-licensing } & Tsai (2009) & \multirow[t]{2}{*}{ In-licens } & \multirow{2}{*}{$\begin{array}{l}\text { Number of intellectual property } \\
\text { rights of other organisations, such as } \\
\text { patents, the firm bought or used }\end{array}$} \\
\hline & Tsai and Wang (2009) & & \\
\hline \multirow[t]{4}{*}{$\begin{array}{l}\text { Institutional } \\
\text { collaboration }\end{array}$} & $\begin{array}{l}\text { Aschhoff and } \\
\text { Schmidt (2008) }\end{array}$ & \multirow[t]{4}{*}{ Inst coll } & \multirow{4}{*}{$\begin{array}{l}\text { Number of university, research } \\
\text { centre, public and non-profit } \\
\text { organisation collaborations for } \\
\text { knowledge inflow in which } \\
\text { the firm engaged }\end{array}$} \\
\hline & Belderbos et al. (2006) & & \\
\hline & Hwang and Lee (2010) & & \\
\hline & $\begin{array}{l}\text { Laursen and } \\
\text { Salter (2006) }\end{array}$ & & \\
\hline \multirow{2}{*}{$\begin{array}{l}\text { Platform } \\
\text { biotech firm }\end{array}$} & Chiaroni et al. (2010) & \multirow{2}{*}{$\begin{array}{l}\text { Plat } \\
\text { biotech }\end{array}$} & \multirow{2}{*}{$\begin{array}{l}\text { Number of specialised firms } \\
\text { focused on the development } \\
\text { and commercialisation of new } \\
\text { biotech-based technologies with } \\
\text { which the firm collaborated for } \\
\text { knowledge inflow }\end{array}$} \\
\hline & Chiaroni et al. (2007) & & \\
\hline
\end{tabular}


Table 2 OI practices, literature, variable names and constructs (continued)

\begin{tabular}{|c|c|c|c|}
\hline OI practices & Literature & Variables & $\begin{array}{c}\text { Measurements } \\
\text { (for the period 2001-2010) }\end{array}$ \\
\hline \multicolumn{4}{|l|}{ Inbound practices } \\
\hline $\begin{array}{l}\text { Purchasing of } \\
\text { scientific services }\end{array}$ & Chiaroni et al. (2010) & Purch serv & $\begin{array}{l}\text { Number of scientific } \\
\text { services the firm purchased }\end{array}$ \\
\hline \multirow[t]{3}{*}{ Venture capital } & $\begin{array}{l}\text { Benson and } \\
\text { Ziedonis (2009) }\end{array}$ & \multirow[t]{3}{*}{ Vent cap } & \multirow{3}{*}{$\begin{array}{l}\text { Number of research studies } \\
\text { supported by venture capitalists } \\
\text { in which the firm engaged }\end{array}$} \\
\hline & $\begin{array}{l}\text { Dushnitsky and } \\
\text { Lenox (2005) }\end{array}$ & & \\
\hline & $\begin{array}{l}\text { Wadhwa and } \\
\text { Kotha (2006) }\end{array}$ & & \\
\hline Acquisition & $\begin{array}{l}\text { Vanhaverbeke } \\
\text { et al. (2002) }\end{array}$ & Acquis & $\begin{array}{l}\text { Number of acquisitions in which the } \\
\text { firm engaged }\end{array}$ \\
\hline \multicolumn{4}{|l|}{ Outbound practices } \\
\hline \multirow[t]{2}{*}{ Out-licensing } & Lichtenthaler (2011) & \multirow[t]{2}{*}{ Out-licens } & \multirow{2}{*}{$\begin{array}{l}\text { Number of patents and copyrights } \\
\text { the firm sold or offered to other } \\
\text { organisations }\end{array}$} \\
\hline & $\begin{array}{l}\text { Lichtenthaler and } \\
\text { Ernst (2007) }\end{array}$ & & \\
\hline Divest & $\begin{array}{l}\text { Lee and Madhavan } \\
\text { (2010) }\end{array}$ & Divest & $\begin{array}{l}\text { Number of divisions, business units } \\
\text { and product lines the firm divested }\end{array}$ \\
\hline \multirow[t]{2}{*}{ Spinoff } & $\begin{array}{l}\text { Chesbrough and } \\
\text { Rosenbloom (2002) }\end{array}$ & \multirow[t]{2}{*}{ Spinoff } & \multirow[t]{2}{*}{$\begin{array}{l}\text { Number of divisions, business units } \\
\text { and product lines the firm spun off }\end{array}$} \\
\hline & Chesbrough (2003) & & \\
\hline $\begin{array}{l}\text { Supply of } \\
\text { scientific services }\end{array}$ & Chiaroni et al. (2010) & Supp serv & $\begin{array}{l}\text { Number of scientific } \\
\text { services the firm sold }\end{array}$ \\
\hline \multirow{3}{*}{$\begin{array}{l}\text { External } \\
\text { technology } \\
\text { commercialisation }\end{array}$} & Lichtenthaler (2005) & \multirow[t]{3}{*}{ Ext comm } & \multirow{3}{*}{$\begin{array}{l}\text { Number of agreements for } \\
\text { commercialisation and distribution } \\
\text { in which the firm engaged }\end{array}$} \\
\hline & $\begin{array}{l}\text { Lichtenthaler and } \\
\text { Ernst (2007) }\end{array}$ & & \\
\hline & Kutvonen (2011) & & \\
\hline \multicolumn{4}{|l|}{ Coupled practices } \\
\hline \multirow[t]{2}{*}{ Co-patent } & $\begin{array}{l}\text { Lecocq and } \\
\text { Van Looy (2009) }\end{array}$ & \multirow[t]{2}{*}{ Co-patent } & \multirow{2}{*}{$\begin{array}{l}\text { Number of patents the firm } \\
\text { co-developed with other } \\
\text { organisations or universities }\end{array}$} \\
\hline & Lin et al. (2012) & & \\
\hline \multirow[t]{4}{*}{ Strategic alliance } & Belderbos et al. (2010) & \multirow[t]{4}{*}{ Strat all } & \multirow{4}{*}{$\begin{array}{l}\text { Number of R\&D alliances and } \\
\text { manufacturing alliances for } \\
\text { co-manufacturing aims in } \\
\text { which the firm engaged }\end{array}$} \\
\hline & Faems et al. (2005) & & \\
\hline & $\begin{array}{l}\text { Fey and Birkinshaw } \\
(2005)\end{array}$ & & \\
\hline & Lin et al. (2012) & & \\
\hline \multirow[t]{2}{*}{$\begin{array}{l}\text { Strategic joint } \\
\text { venture }\end{array}$} & $\begin{array}{l}\text { Gassmann and } \\
\text { Enkel (2004) }\end{array}$ & \multirow[t]{2}{*}{ Strat JV } & \multirow{2}{*}{$\begin{array}{l}\text { Number of R\&D JV and } \\
\text { manufacturing JV for } \\
\text { co-manufacturing aims } \\
\text { in which the firm engaged }\end{array}$} \\
\hline & Sampson (2007) & & \\
\hline
\end{tabular}

To control for firm-level factors that might influence a firm's innovation and economic-financial performance, we include in the analysis several control variables. First of all, we control for the age of the firm (Age) and for firm size (Size), calculated by 
the $\log$ of the total number of employees. Moreover, we control for the degree of globalisation $(G l o b)$ as the percentage of sales on the international market and for the number of trademarks developed (Trad). Finally, we control for the R\&D expenditures $(R \& D \exp )$ as the slope of $\mathrm{R} \& \mathrm{D}$ expenses in the last ten years.

\section{Results}

Table 3 provides the descriptive statistics, with minimum and maximum values, means, and standard deviations of the variables, while Table 4 displays the correlation matrix.

Table 3 Descriptive statistics

\begin{tabular}{|c|c|c|c|c|c|}
\hline & & Mean & Std. dev. & Min & $\operatorname{Max}$ \\
\hline 1 & Age & 22.40 & 12.49 & 6 & 124 \\
\hline 2 & Size & 5.73 & 1.31 & 2.92 & 10.02 \\
\hline 3 & Trad & 22.08 & 32.22 & 0 & 255 \\
\hline 4 & Glob & 1.77 & 0.85 & 1 & 5 \\
\hline 5 & $R \& D \exp$ & 12.18 & 33.21 & -31 & 255 \\
\hline 6 & In-licens & 22.35 & 17.99 & 0 & 76 \\
\hline 7 & Inst coll & 14.85 & 17.12 & 0 & 103 \\
\hline 8 & Plat biotech & 1.53 & 4.37 & 0 & 35 \\
\hline 9 & Purch serv & 1.90 & 3.98 & 0 & 25 \\
\hline 10 & Vent cap & 2.16 & 3.77 & 0 & 12 \\
\hline 11 & Acquis & 2.32 & 3.32 & 0 & 18 \\
\hline 12 & Out-licens & 25.91 & 30.84 & 0 & 214 \\
\hline 13 & Divest & 0.95 & 1.34 & 0 & 5 \\
\hline 14 & Spinoff & 0.20 & 0.95 & 0 & 9.0 \\
\hline 15 & Supp serv & 2.20 & 3.85 & 0 & 11 \\
\hline 16 & Ext comm & 18.80 & 23.97 & 0 & 233 \\
\hline 17 & Co-patent & 3.28 & 7.30 & 0 & 50 \\
\hline 18 & Strat all & 37.91 & R32.06 & 0 & 238 \\
\hline 19 & Strat JV & 1.97 & 5.93 & 0 & 50 \\
\hline 20 & Patents & 46.60 & 78.82 & 0 & 527 \\
\hline 21 & Growth of revenue & 67.72 & 213.04 & -24.35 & 1588.4 \\
\hline
\end{tabular}

To control for the multicollinearity problem among variables, we check the variance inflation factors (VIFs). The highest individual VIF score among all the variables is 2.71, whereas the mean VIF score is 1.53 , thus multicollinearity among variables is not a problem in our analysis (Lin et al., 2012). 
Table 4 Correlation matrix

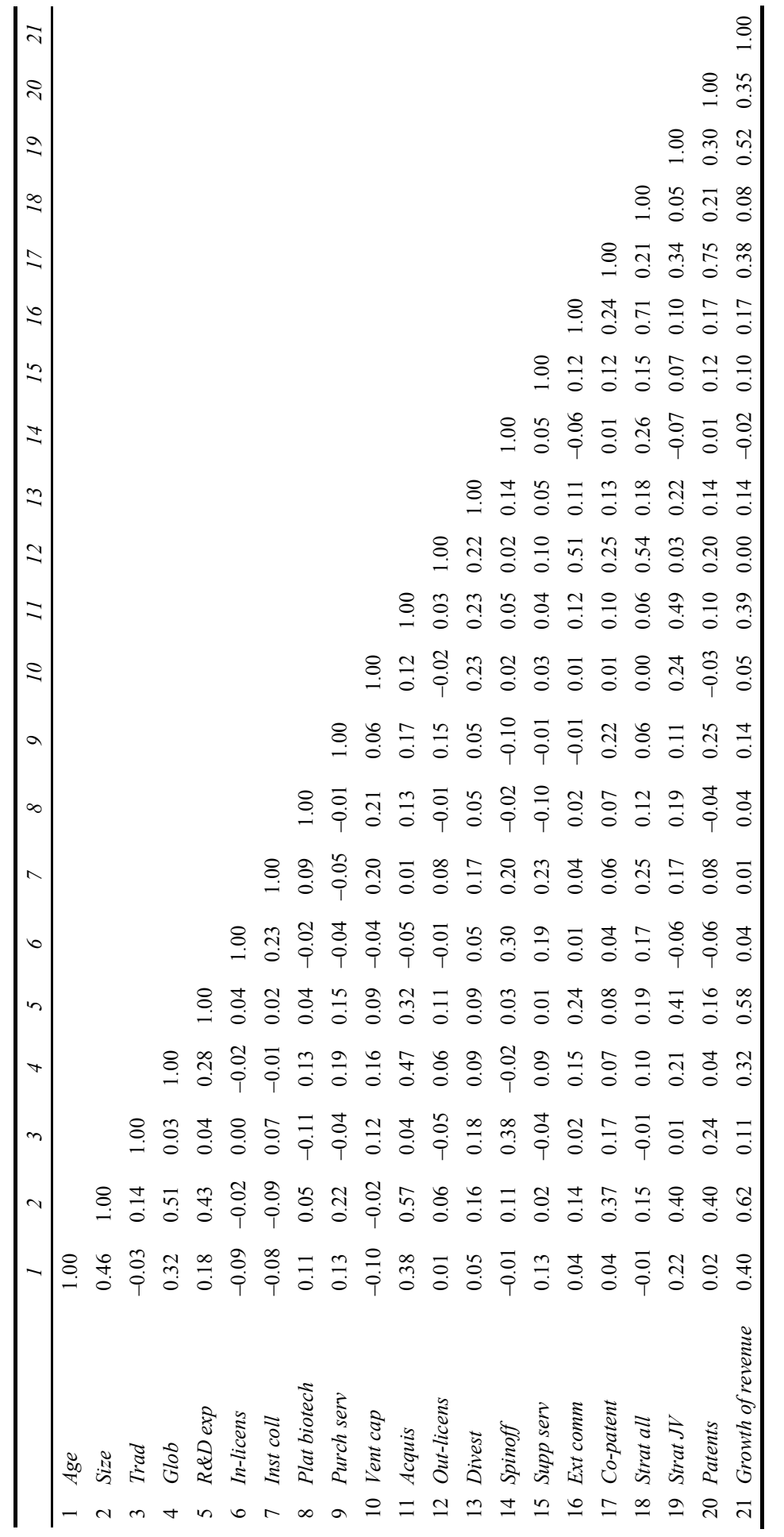


The first dependent variable of this study, i.e. the total number of patents, is a countable variable, and takes only non-negative integer values. Prior studies assert that the Poisson regression model provides a natural model for modelling such data (Lin et al., 2012). However, in our case the underlying assumption of the Poisson model of equality of the mean and variance of the dependent variable is violated, leading to inefficient Poisson estimates. Consequently, in line with other works in OI literature, we utilise a negative binomial regression analysis to overcome the problem of over-dispersion (Lin et al., 2012; Wadhwa and Kotha, 2006). Whereas, as regards to the second dependent variable, the growth of revenue, since it is a continuous quantitative measure we use an OLS regression model.

Table 5 Negative binomial for innovation performance and OLS for financial performance

\begin{tabular}{|c|c|c|c|c|c|c|c|c|}
\hline \multirow{2}{*}{$\begin{array}{l}\text { Independent } \\
\text { variable }\end{array}$} & \multicolumn{4}{|c|}{$\begin{array}{c}\text { Dependent variable - } \\
\text { Patents }\end{array}$} & \multicolumn{4}{|c|}{$\begin{array}{l}\text { Dependent variable- } \\
\text { Growth of revenue }\end{array}$} \\
\hline & Model 1 & Model 2 & Model 3 & Model 4 & Model 5 & Model 6 & Model 7 & Model 8 \\
\hline \multicolumn{9}{|l|}{ Controls } \\
\hline Age & $\begin{array}{l}-0.02^{*} \\
(0.01)\end{array}$ & $\begin{array}{l}-0.02 * * \\
(0.00)\end{array}$ & $\begin{array}{l}-0.02 * * \\
(0.00)\end{array}$ & $\begin{array}{l}-0.01 \\
(0.00)\end{array}$ & $\begin{array}{l}-0.01 \dagger \\
(0.00)\end{array}$ & $\begin{array}{l}-0.01 \dagger \\
(0.01)\end{array}$ & $\begin{array}{l}-0.01 \dagger \\
(0.01)\end{array}$ & $\begin{array}{l}-0.02 * \\
(0.01)\end{array}$ \\
\hline Size & $\begin{array}{l}0.65^{* * *} \\
(0.11)\end{array}$ & $\begin{array}{l}0.76^{* * *} \\
(0.11)\end{array}$ & $\begin{array}{l}0.73 * * * \\
(0.11)\end{array}$ & $\begin{array}{l}0.36^{* * *} \\
(0.11)\end{array}$ & $\begin{array}{l}-0.01 \dagger \\
(0.00)\end{array}$ & $\begin{array}{l}-0.01 \\
(0.00)\end{array}$ & $\begin{array}{l}-0.01 \\
(0.00)\end{array}$ & $\begin{array}{l}-0.01 \\
(0.00)\end{array}$ \\
\hline Trad & $\begin{array}{l}0.00 \\
(0.00)\end{array}$ & $\begin{array}{l}0.00 \\
(0.00)\end{array}$ & $\begin{array}{l}0.01 * \\
(0.03)\end{array}$ & $\begin{array}{l}0.01 * * * \\
(0.03)\end{array}$ & $\begin{array}{l}-0.14 \\
(0.13)\end{array}$ & $\begin{array}{l}-0.13 \\
(0.12)\end{array}$ & $\begin{array}{l}-0.10 \\
(0.12)\end{array}$ & $\begin{array}{l}0.02 \\
(0.14)\end{array}$ \\
\hline Glob & $\begin{array}{l}-0.27^{*} \\
(0.14)\end{array}$ & $\begin{array}{l}-0.23 \dagger \\
(0.15)\end{array}$ & $\begin{array}{l}-0.37 * * \\
(0.14)\end{array}$ & $\begin{array}{l}-0.41 * * * \\
(0.14)\end{array}$ & $\begin{array}{l}0.28 \dagger \\
(0.17)\end{array}$ & $\begin{array}{l}0.32 \dagger \\
(0.18)\end{array}$ & $\begin{array}{l}0.30 \dagger \\
(0.18)\end{array}$ & $\begin{array}{l}0.23 \\
(0.19)\end{array}$ \\
\hline$R \& D \exp$ & $\begin{array}{l}-0.50 \\
(0.16)\end{array}$ & $\begin{array}{l}-0.00 \\
(0.16)\end{array}$ & $\begin{array}{l}-0.05 \\
(0.15)\end{array}$ & $\begin{array}{l}0.42 * \\
(0.21)\end{array}$ & $\begin{array}{l}0.51^{*} \\
(0.24)\end{array}$ & $\begin{array}{l}0.50^{*} \\
(0.23)\end{array}$ & $\begin{array}{l}0.52 * \\
(0.22)\end{array}$ & $\begin{array}{l}0.49 \dagger \\
(0.29)\end{array}$ \\
\hline \multicolumn{9}{|l|}{ Inbound } \\
\hline In-licens & & $\begin{array}{l}-0.01 \\
(0.00)\end{array}$ & $\begin{array}{l}-0.01 \dagger \\
(0.00)\end{array}$ & $\begin{array}{l}-0.01 * * * \\
(0.00)\end{array}$ & & $\begin{array}{l}0.02 * * \\
(0.00)\end{array}$ & $\begin{array}{l}0.02 * * * \\
(0.00)\end{array}$ & $\begin{array}{l}0.02 * * * \\
(0.00)\end{array}$ \\
\hline Inst coll & & $\begin{array}{l}0.01 * * \\
(0.00)\end{array}$ & $\begin{array}{l}0.01 * \\
(0.00)\end{array}$ & $\begin{array}{l}0.01 * \\
(0.00)\end{array}$ & & $\begin{array}{l}0.00 \\
(0.00)\end{array}$ & $\begin{array}{l}0.00 \\
(0.00)\end{array}$ & $\begin{array}{l}0.01 \dagger \\
(0.00)\end{array}$ \\
\hline Plat biotech & & $\begin{array}{l}0.01 \\
(0.03)\end{array}$ & $\begin{array}{l}-0.01 \\
(0.03)\end{array}$ & $\begin{array}{l}-0.05^{* *} \\
(0.02)\end{array}$ & & $\begin{array}{l}0.03 \\
(0.02)\end{array}$ & $\begin{array}{l}0.03 \\
(0.02)\end{array}$ & $\begin{array}{l}0.04 \dagger \\
(0.02)\end{array}$ \\
\hline Purch serv & & $\begin{array}{l}0.09 * * \\
(0.03)\end{array}$ & $\begin{array}{l}0.07 * * \\
(0.03)\end{array}$ & $\begin{array}{l}0.05^{*} \\
(0.02)\end{array}$ & & $\begin{array}{l}0.00 \\
(0.02)\end{array}$ & $\begin{array}{l}0.00 \\
(0.02)\end{array}$ & $\begin{array}{l}0.01 \\
(0.02)\end{array}$ \\
\hline Vent cap & & $\begin{array}{l}-0.02 \\
(0.03)\end{array}$ & $\begin{array}{l}-0.01 \\
(0.02)\end{array}$ & $\begin{array}{l}-0.04 \dagger \\
(0.02)\end{array}$ & & $\begin{array}{l}-0.05 \\
(0.03)\end{array}$ & $\begin{array}{l}-0.03 \\
(0.03)\end{array}$ & $\begin{array}{l}-0.03 \\
(0.04)\end{array}$ \\
\hline Acquis & & $\begin{array}{l}-0.10^{* *} \\
(0.03)\end{array}$ & $\begin{array}{l}-0.10^{* * *} \\
(0.03)\end{array}$ & $\begin{array}{l}-0.04 \\
(0.03)\end{array}$ & & $\begin{array}{l}-0.10 \\
(0.03)\end{array}$ & $\begin{array}{l}-0.01 \\
(0.03)\end{array}$ & $\begin{array}{l}-0.01 \\
(0.04)\end{array}$ \\
\hline
\end{tabular}

Notes: $* * * \mathrm{p}<.001, * * \mathrm{p}<.01, * \mathrm{p}<.05, \dagger \mathrm{p}<.10$

Robust standard errors are in parentheses. 
Open innovation and firms' performance

Table 5 Negative binomial for innovation performance and OLS for financial performance (continued)

\begin{tabular}{|c|c|c|c|c|c|c|c|c|}
\hline \multirow{2}{*}{$\begin{array}{l}\text { Independent } \\
\text { variable }\end{array}$} & \multicolumn{4}{|c|}{$\begin{array}{l}\text { Dependent variable- } \\
\text { patents }\end{array}$} & \multicolumn{4}{|c|}{$\begin{array}{l}\text { Dependent variable- } \\
\text { growth of revenue }\end{array}$} \\
\hline & Model 1 & Model 2 & Model 3 & Model 4 & Model 5 & Model 6 & Model 7 & Model 8 \\
\hline \multicolumn{9}{|l|}{ Outbound } \\
\hline Out-licens & & & $\begin{array}{l}0.01 * \\
(0.00)\end{array}$ & $\begin{array}{l}0.00 \\
(0.00)\end{array}$ & & & $\begin{array}{l}0.01 \\
(0.00)\end{array}$ & $\begin{array}{l}0.01^{*} \\
(0.00)\end{array}$ \\
\hline Divest & & & $\begin{array}{l}0.01 \\
(0.08)\end{array}$ & $\begin{array}{l}0.02 \\
(0.07)\end{array}$ & & & $\begin{array}{l}-0.19 * \\
(0.09)\end{array}$ & $\begin{array}{l}-0.17 \dagger \\
(0.09)\end{array}$ \\
\hline Spinoff & & & $\begin{array}{l}-0.06 \\
(0.12)\end{array}$ & $\begin{array}{l}-0.22 \dagger \\
(0.13)\end{array}$ & & & $\begin{array}{l}-0.14^{*} \\
(0.96)\end{array}$ & $\begin{array}{l}-0.05 \\
(0.09)\end{array}$ \\
\hline Supp serv & & & $\begin{array}{l}0.03 \\
(0.02)\end{array}$ & $\begin{array}{l}0.03 \\
(0.02)\end{array}$ & & & $\begin{array}{l}-0.01 \\
(0.03)\end{array}$ & $\begin{array}{l}-0.01 \\
(0.03)\end{array}$ \\
\hline Ext comm & & & $\begin{array}{l}0.00 \\
(0.00)\end{array}$ & $\begin{array}{l}-0.02^{*} \\
(0.00)\end{array}$ & & & $\begin{array}{l}-0.01 \\
(0.03)\end{array}$ & $\begin{array}{l}0.01 \\
(0.00)\end{array}$ \\
\hline \multicolumn{9}{|l|}{ Coupled } \\
\hline Co-patent & & & & $\begin{array}{l}0.08^{* * *} \\
(0.02)\end{array}$ & & & & $\begin{array}{l}-0.23 \dagger \\
(0.14)\end{array}$ \\
\hline Strat all & & & & $\begin{array}{l}0.01 * * * \\
(0.00)\end{array}$ & & & & $\begin{array}{l}-0.01 \dagger \\
(0.00)\end{array}$ \\
\hline Strat JV & & & & $\begin{array}{l}0.01 \\
(0.01)\end{array}$ & & & & $\begin{array}{l}-0.01 \\
(0.02)\end{array}$ \\
\hline Numobs & 120 & 120 & 120 & 120 & 120 & 120 & 120 & 120 \\
\hline $\begin{array}{l}\text { Wald } \chi^{2} \\
\text { and } \mathrm{R}^{2}\end{array}$ & $42.32 * * *$ & $54.60 * * *$ & $77.45^{* * *}$ & $107.23 * * *$ & $0.08 * * *$ & $0.18^{* * *}$ & $0.22 * * *$ & $0.25 * * *$ \\
\hline
\end{tabular}

Notes: $* * * p<.001, * * p<.01, * p<.05, \dagger p<.10$

Robust standard errors are in parentheses.

Table 5 presents the results of the regression analysis estimated by negative binomial regression to explain the innovation performance, and the OLS regression results to explain the economic-financial performance. As regards the innovation performance, Model 1 is the base-line model, including only the control variables. Model 2 shows the result of regression, analysing the effects of six inbound OI practices on innovation performance, while Model 3 includes the main effects of five outbound OI practices. Finally, Model 4, the full model, adds the variables related to the three coupled OI practices. Looking at Wald $\chi^{2}$ statistics, the addition of these variables in Model 2, Model 3, and Model 4 increases the overall model fit as compared with Model $1\left(\Delta \chi^{2}=\right.$ 64.91).

As regards the economic-financial performance, in Model 5 we enter only the control variables and we find that they can explain low amount of the variance $\left(\mathrm{R}^{2}=0.08\right)$. The main effects of inbound OI practices on financial performance are entered in Model 6. After these six variables are included, there is a certain improvement of the model fit 
$\left(\mathrm{R}^{2}=0.18\right)$. In Model 7, we introduce the main effects of outbound practices. The introduction of these five variables improves the model fit $\left(\mathrm{R}^{2}=0.22\right)$. Finally in Model 8, we introduce the variables related to the coupled practices. This increases the model fit $\left(\mathrm{R}^{2}=0.25\right)$. We use Models 4 and 8 to examine the theoretical expectations addressed earlier and to interpret the results.

Several control variables are significantly related to innovation performance. Size is positively associated with the number of patents, indicating that bigger NBI companies report better innovation outcomes. The international orientation (Glob) has a negative impact on firm innovation; this result indicates that the higher the capacity of NBI firms to reach new markets, the lower the innovation outcomes. The coefficients of Trad and $R \& D \exp$ are positively related with the innovation performance measure; this confirms that, even in the biopharmaceutical industry, such variables influence patents' development. Age is not significant. Concerning financial performance, only Age and $R \& D \exp$ are significant. Age is negatively associated with the growth of the revenue indicating that younger NBI companies report better economic-financial performance than older ones. $\mathrm{R} \& \mathrm{D}$ expenditure $(R \& D \exp )$ is positively associated with the growth of revenue.

Hypothesis 1 receives support for the practices In-licens, Inst coll and Plat biotech. In particular, the amount of in-licensing agreements the firm engages in is positively related to the growth of revenue while negatively related to the number of patents. The amount of institutional collaborations the firm engages in is positively related both to the growth of revenue and the number of patents. Finally, the amount of collaborations with the platform biotech firms is positively related to the growth of revenue while negatively related to the number of patents. On the other hand, Purch serv is positively related only to the number of patents, while Vent cap is negatively related to them. No inbound practices are significantly related only to the economic-financial measure.

Hypothesis 2 does not receive support since the variables that are significant in Model 4 are not significant in Model 8. Specifically, Spin-off and Ext comm are negatively related only to the innovation measure, while Out-licens and Divest are positively related only to the economic-financial measure.

Hypothesis 3 receives support for two practices, explicitly Co-patents and Strat all. In particular, it emerges that the number of co-patents the firm develops with other organisations is positively related to the number of patents while it is negatively related to the growth of revenue. Similarly, the number of strategic alliances the firm engages in is positively related to the number of patents while it is negatively related to the growth of revenue. No coupled practices are significantly related to only one of the performance measures of our model.

\section{Findings and implications}

The first important finding is that although a lot of research works argue that OI processes bring benefits to both innovation and economic-financial performance, we find that only five out of 14 investigated OI practices affect both such performance dimensions. Also, their concurrent effects have either a different or same sign. Specifically, as shown in the matrix of Table 6, we find that institutional collaborations affect positively both kinds of performance. 
Table 6 OI practices affecting both innovation and financial performance

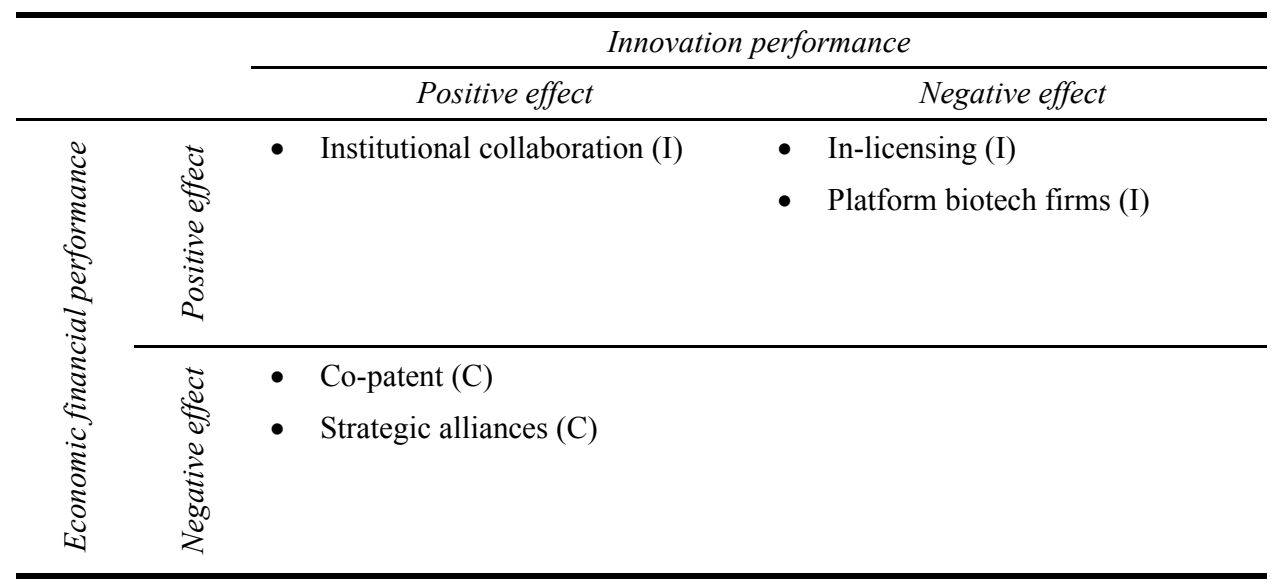

As regards the second quarter of the matrix, the two inbound OI practices, in-licensing and platform biotech firms, affect both kinds of performance but they have a discordant effect; indeed, they negatively affect the innovation performance while positively influencing the economic-financial performance. Also the two coupled OI practices, co-patents and strategic alliances, seem to impact on both the dimensions with conflicting effects. Specifically, as reported in the third quarter of the matrix, they positively affect the innovation performance while negatively influencing the financial performance. Finally, not one of the previous 14 OI practices seems to have a concurrent negative effect on both innovation and economic-financial performance.

Based on this finding we provide empirically explanations on how a given OI practice, while bringing advantages from an economic-financial point of view, may lead to innovation performance deterioration, or vice versa. Thus, considering the concurrent effect of OI practices on both such performance dimensions may help managers in making the right decision about what portfolio of OI practices to adopt, depending on their strategic objectives.

Second, although a lot of empirical papers demonstrate that a given level of adoption of inbound, outbound or coupled OI processes is correlated to improvements in innovation or economic-financial performance, we find that when considering specific OI practice adoption, this is not always true. There are some OI practices (no matter whether they are inbound, outbound or coupled OI) that do not affect performance at all. We resume these results in the matrix of Table 7.

Apart from practices belonging to the first quarter, which have already been discussed in Table 6, it is of great interest to analyse the OI practices belonging to the other three quarters. In the second quarter of the matrix, the two outbound OI practices, out-licensing and divest, are significant in the economic-financial models, while they are not significant in innovation performance. On the contrary, as reported in the third quarter of the matrix, the two inbound OI practices, purchasing of scientific service and venture capital, and the two outbound OI practices, spin-off and external technology commercialisation, are significant in the innovation models while they are not significant in economic-financial performance. Finally, we find three practices (acquisition, supply of scientific services, and strategic joint ventures) whose adoption is not significant with respect to both the performance dimensions. Consequently, exploring the impact of single 
and specific OI practice on performance, instead of just OI adoption intensity level, brings different and new conclusions. Thus, once again, a punctual analysis of the significance of each OI practice on both kinds of performance will help managers in designing their portfolio of practices to better achieve specific objectives.

Table 7 Significance of effect of OI practices on performance

\begin{tabular}{|c|c|c|c|}
\hline & \multicolumn{2}{|c|}{ Innovation performance } \\
\hline & & Significant & Non-significant \\
\hline 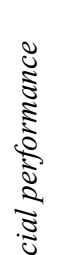 & 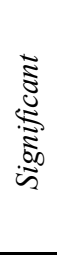 & $\begin{array}{ll}\text { - } & \text { In-licensing (I) } \\
\text { - } & \text { Institutional collaboration (I) } \\
\text { - } & \text { Platform biotech firms (I) } \\
\text { - } & \text { Co-patents (C) } \\
\text { - } & \text { Strategic alliance (C) }\end{array}$ & $\begin{array}{ll}\text { - } & \text { Out-licensing }(\mathrm{O}) \\
\text { - } & \text { Divest }(\mathrm{O})\end{array}$ \\
\hline 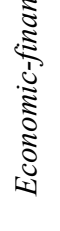 & 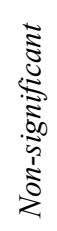 & 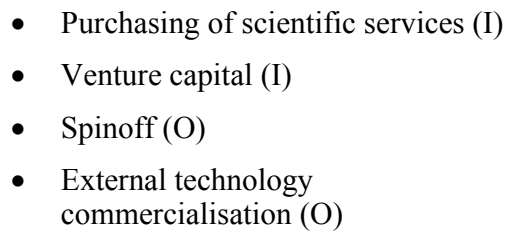 & $\begin{array}{ll}\text { - } & \text { Acquisition (I) } \\
\text { - } & \text { Supply of scientific service }(\mathrm{O}) \\
\text { - } & \text { Strategic joint venture }(\mathrm{C})\end{array}$ \\
\hline
\end{tabular}

Moreover, having investigated 14 different OI practices separately leads us to argue that using aggregate measures of OI implementation might bring new findings concerning inbound, outbound and coupled OI processes. In fact, our results show that different practices belonging to the same OI process (inbound, outbound, coupled) affect firm performance in very opposite ways. For example, collaborations with platform biotech firms for inflowing knowledge and purchasing of scientific services are usually considered together in a single aggregate measure of inbound OI (Bianchi et al., 2011; Chiaroni et al., 2010). We argue that, when considered separately, one may observe that they affect innovation performance in an opposite way. The amount of platform biotech firms' collaborations is negatively related to the number of patents (while the number of purchase of services is positively related). Aggregate measures of OI practices might not evidence such discordant effects by counterbalancing them.

\section{Conclusions}

On the basis of a sample of 120 biopharmaceutical companies, the present paper explores a topic that is crucial both for managers and practitioners, that is the relationship between the adoption of OI practices and innovation and economic-financial performance. To the best of our knowledge, to date no scholars have investigated the simultaneous influence of practices belonging to inbound, outbound and coupled OI processes on both innovation and economic-financial performance. Surprisingly, our findings show that considering OI practices separately, not aggregately, produces new and different conclusions related to the concurrent effect of each of them on both economic-financial and innovation performance. This opens up the way for new research development about the concept of wideness, besides the already known breadth and depth dimensions of OI 
(Laursen and Salter, 2006), meaning the contemporary adoption of OI practices (even belonging to the same or different OI process - inbound, outbound and coupled) and its impact on performance. Second, our findings have interesting implications for managers who are adopting OI strategies for improving innovation and economic-financial performance. Indeed, when designing OI strategy the manager should be well acquainted with the whole portfolio of possible practices she/he may adopt. The results of such a paper, in fact, could help managers not only in selecting the most appropriate practice (existing literature already suggests this), but also in evaluating the concurrent effects of these sets of practices on both economic-financial and innovation performance.

\section{References}

Ahuja, G. (2000) 'Collaboration networks, structural holes, and innovation: a longitudinal study', Administrative Science Quarterly, Vol. 45, No. 3, pp.425-455.

Aschhoff, B. and Schmidt, T. (2008) 'Empirical evidence on the success of R\&D cooperation happy together?', Review of Industrial Organization, Vol. 33, No. 1, pp.41-62.

Bae, J. and Gargiulo, M. (2004) 'Partner substitutability, alliance network structure, and firm profitability in the telecommunications industry', Academy of Management Journal, Vol. 47, No. 6, pp.843-859.

Bapuji, H., Loree, D. and Crossan, M. (2011) 'Connecting external knowledge usage and firm performance: an empirical analysis', Journal of Engineering and Technology Management, Vol. 28, No. 4, pp.215-231.

Belderbos, R., Carree, M. and Lokshin, B. (2004) 'Cooperative R\&D and firm performance', Research Policy, Vol. 33, No. 10, pp.1477-1492.

Belderbos, R., Carree, M. and Lokshin, B. (2006) 'Complementarity in R\&D cooperation strategies', Review of Industrial Organization, Vol. 28, No. 4, pp.401-426.

Belderbos, R., Faems, D., Leten, B. and Van Looy, B. (2010) 'Technological activities and their impact on the financial performance of the firm: exploitation and exploration within and between firms', Journal of Product Innovation Management, Vol. 27, No. 6, pp.869-882.

Benson, D. and Ziedonis, R.H. (2009) 'Corporate venture capital as a window on new technologies: implications for the performance of corporate investors when acquiring startups', Organization Science, Vol. 20, No. 2, pp.329-351.

Bianchi, M., Cavaliere, A., Chiaroni, D., Frattini, F. and Chiesa, V. (2011) 'Organisational modes for open innovation in the bio-pharmaceutical industry: an exploratory analysis', Technovation, Vol. 31, No. 1, pp.22-33.

Chang, Y.C., Chang, H.T., Chi, H.R., Chen, M.H. and Deng, L.L. (2012) 'How do established firms improve radical innovation performance? The organizational capabilities view', Technovation, Vol. 32, Nos. 7-8, pp.441-451.

Cheng, C.C. and Huizingh, E.K. (2014) 'When is open innovation beneficial? The role of strategic orientation', Journal of Product Innovation Management, Vol. 31, No. 5, pp.1235-1253.

Chesbrough, H. (2003) Open Innovation: The New Imperative for Creating and Profiting from Technology, Harvard Business School Press, Boston.

Chesbrough, H. and Rosenbloom, R.S. (2002) 'The role of the business model in capturing value from innovation: evidence from Xerox corporation's technology spin-off companies', Industrial and Corporate Change, Vol. 11, No. 3, pp.529-555.

Chiang, Y.H. and Hung, K.P. (2010) 'Exploring open search strategies and perceived innovation performance from the perspective of inter-organizational knowledge flows', $R \& D$ Management, Vol. 40, No. 3, pp.292-299. 
Chiaroni, D., Chiesa, V. and Frattini, F. (2010) 'Un-ravelling the process from closed to open innovation: evidence from mature, asset-intensive industries', R\&D Management, Vol. 40, No. 3, pp.222-245.

Chiaroni, D., Chiesa, V., De Massis, A. and Frattini, F. (2007) 'The knowledge bridging role of technical and scientific services in knowledge-intensive industries', International Journal of Technology Management, Vol. 41, Nos. 3/4, pp.249-272.

Cohen, W.M. and Levinthal, D.A. (1990) 'Absorptive capacity: a new perspective on learning and innovation', Administrative Science Quarterly, Vol. 35, No. 1, pp.128-152.

Das, T.K. and Teng, B.S. (1998) 'Between trust and control: developing confidence in partner cooperation in alliances', Academy of Management Review, Vol. 23, No. 3, pp.491-512.

Dushnitsky, G. and Lenox, M.J. (2005) 'When do incumbents learn from entrepreneurial ventures? Corporate venture capital and investing firm innovation rates', Research Policy, Vol. 34, No. 5, pp.615-639.

Ebersberger, B., Bloch, C., Herstad, S. and Van de Velde, E. (2012) 'Open innovation practices and their effect on innovation performance', International Journal of Innovation and Technology Management, Vol. 9, No. 6, pp.1250040-63.

Faems, D., de Visser, M., Andries, P. and Van Looy, B. (2010) 'Technology alliance portfolios and financial performance: value-enhancing and cost-increasing effects of open innovation', Journal of Product Innovation Management, Vol. 27, No. 6, pp.785-796.

Faems, D., Van Looy, B. and Debackere, K. (2005) 'Interorganizational collaboration and innovation: toward a portfolio approach', Journal of Product Innovation Management, Vol. 22, No. 3, pp.238-250.

Ferrary, M. (2011) 'Specialized organizations and ambidextrous clusters in the open innovation paradigm', European Management Journal, Vol. 29, No. 3, pp.181-192.

Fey, C. and Birkinshaw, J. (2005) 'External sources of knowledge, governance mode and R\&D performance', Journal of Management, Vol. 31, No. 4, pp.597-621.

Foss, N.J., Laursen, K. and Pedersen, T. (2011) 'Linking customer interaction and innovation: the mediating role of new organizational practices', Organization Science, Vol. 22, No. 4, pp.980-999.

Gassmann, O. and Enkel, E. (2004) 'Towards a theory of open innovation: three core process archetypes', Paper presented at the R\&D Management Conference, 6-9 July 2004, Lisbon, Portugal.

Gassmann, O., Enkel, E. and Chesbrough, H. (2010) 'The future of open innovation', $R \& D$ Management, Vol. 40, No. 3, pp.213-221.

George, G., Zahra, S.A., Wheatley, K.K. and Khan, R. (2001) 'The effects of alliance portfolio characteristics and absorptive capacity on performance: a study of biotechnology firms', Journal of High Technology Management Research, Vol. 12, No. 2, pp.205-226.

Gilsing, V., Nooteboom, B., Vanhaverbeke, W., Duysters, G. and van den Oord, A. (2008) 'Network embeddedness and the exploration of novel technologies: technological distance, betweenness centrality and density', Research Policy, Vol. 37, No. 10, pp.1717-1731.

Grimpe, C. and Kaiser, U. (2010) 'Balancing internal and external knowledge acquisition: the gains and pains from R\&D outsourcing', Journal of Management Studies, Vol. 47, No. 8, pp.1483-1509.

Gronum, S., Verreynne, M.L. and Kastelle, T. (2012) 'The role of networks in small and medium-sized enterprise innovation and firm performance', Special Issue: Small Business and Networked Innovation: Organizational and Managerial Challenges, Vol. 50, No. 2, pp.257-282.

Hagedoorn, J. and Cloodt, M. (2003) 'Measuring innovative performance: is there an advantage in using multiple indicators?', Research Policy, Vol. 32, No. 2, pp.1365-1379.

Huang, F. and Rice, J. (2009) 'The role of absorptive capacity in facilitating "open innovation" outcomes: a study of Australian SMEs in the manufacturing sector', International Journal of Innovation Management, Vol. 13, No. 2, pp.201-220. 
Hung, K.P. and Chiang, Y.K. (2010) 'Open innovation proclivity, entrepreneurial orientation, and perceived firm performance', International Journal of Technology Management, Vol. 52, No. 3, pp.257-274.

Hung, K.P. and Chou, C. (2013) 'The impact of open innovation on firm performance: the moderating effects of internal R\&D and environmental turbulence', Technovation, Vol. 33, No. 10, pp.368-380.

Hwang, J. and Lee, Y. (2010) 'External knowledge search, innovative performance and productivity in the Korean ICT sector', Telecommunications Policy, Vol. 34, No. 10, pp.562-571.

Inauen, M. and Schenker-Wicki, A. (2011) 'The impact of outside-in open innovation on innovation performance', European Journal of Innovation Management, Vol. 14, No. 4, pp.496-520.

Inauen, M. and Schenker-Wicki, A. (2012) 'Fostering radical innovations with open innovation', European Journal of Innovation Management, Vol. 15, No. 2, pp.212-231.

Kang, K.H. and Kang, J. (2009) 'How do firms source external knowledge for innovation? Analysing effects of different knowledge sourcing methods', International Journal of Innovation Management, Vol. 13, No. 1, pp.1-17.

Kim, H. and Park, Y. (2010) 'The effects of open innovation activity on performance of SMEs: the case of Korea', International Journal of Technology Management, Vol. 52, Nos. 3/4, pp.236-256.

Kutvonen, A. (2011) 'Strategic application of outbound open innovation', European Journal of Innovation Management, Vol. 14, No. 4, pp.460-474.

Lasagni, A. (2012) 'How can external relationships enhance innovation in SMEs? New evidence for Europe', Journal of Small Business Management, Vol. 50, No. 2, pp.310-339.

Laursen, K. and Salter, A. (2006) 'Open for innovation: the role of openness in explaining innovation performance among U.K. manufacturing firms', Strategic Management Journal, Vol. 27, No. 2, pp.131-150.

Lazzarotti, V. and Manzini, R. (2009) 'Different modes of open innovation: a theoretical framework and an empirical study', International Journal of Innovation Management, Vol. 13, No. 4, pp.615-636.

Lecocq, C. and Van Looy, B. (2009) 'The impact of collaboration on the technological performance of regions: time invariant or driven by life cycle dynamics? An explorative investigation of European regions in the field of biotechnology', Scientometrics, Vol. 80, No. 3, pp.845-865.

Lee, D. and Madhavan, R. (2010) 'Divestiture and firm performance: a meta-analysis', Journal of Management, Vol. 36, No. 6, pp.1345-1371.

Lee, J. (2006) 'Family firm performance: further evidence', Family Business Review, Vol. 19, No. 2, pp.103-114.

Li, H.L. and Tang, M.J. (2010) 'Vertical integration and innovative performance: the effects of external knowledge sourcing modes', Technovation, Vol. 30, Nos. 7/8, pp.401-410.

Lichtenthaler, U. (2005) 'External commercialization of knowledge: review and research agenda', International Journal of Management Reviews, Vol. 7, No. 4, pp.231-255.

Lichtenthaler, U. (2009) 'Outbound open innovation and its effect on firm performance: examining environmental influences', $R \& D$ Management, Vol. 39, No. 4, pp.317-330.

Lichtenthaler, U. (2011) 'Implementation steps for successful out-licensing', Research Technology Management, Vol. 54, No. 5, pp.47-53.

Lichtenthaler, U. and Ernst, H. (2007) 'External technology commercialization in large firms: results of a quantitative benchmarking study', $R \& D$ Management, Vol. 37, No. 5, pp.383-397.

Lichtenthaler, U. and Ernst, H. (2012) 'Integrated knowledge exploitation: the complementarity of product development and technology licensing', Strategic Management Journal, Vol. 33, No. 5, pp.513-534. 
Lin, B.W. and $\mathrm{Wu}$, C.H. (2010) 'How does knowledge depth moderate the performance of internal and external knowledge sourcing strategies?', Technovation, Vol. 30, Nos. 11/12, pp.582-589.

Lin, C., Wu, Y.J., Chang, C., Wang, W. and Lee, C.Y. (2012) 'The alliance innovation performance of R\&D alliances: the absorptive capacity perspective', Technovation, Vol. 32, No. 5, pp.282-292.

Love, J.H. and Mansury, M.A. (2007) 'External linkages, R\&D and innovation performance in U.S. business services', Industry and Innovation, Vol. 14, No. 5, pp.477-496.

Love, J.H., Roper, S. and Vahter, P. (2013) 'Learning from openness: the dynamics of breadth in external innovation linkages', Strategic Management Journal, Vol. 35, No. 11, pp.1703-1716.

Mazzola, E., Bruccoleri, M. and Perrone, G. (2012) 'The effect of inbound, outbound and coupled innovation on performance', International Journal of Innovation Management, Vol. 16, No. 6, pp.1240008-35.

Mention, A.L. and Asikainen, A.L. (2012) 'Innovation \& productivity: investigating effects of openness in services', International Journal of Innovation Management, Vol. 16, No. 3, pp.1240004-31.

Nadkarni, S. and Narayanan, V.K. (2007) 'Strategic schemas, strategic flexibility and firm performance: the moderating role of industry clockspeed', Strategic Management Journal, Vol. 28, No. 3, pp.243-270.

Neyens, I., Faems, D. and Sels, L. (2010) 'The impact of continuous and discontinuous alliance strategies on startup innovation performance', International Journal of Technology Management, Vol. 52, Nos. 3/4, pp.392-410.

Nieto, M.J. and Rodriguez, A. (2011) 'Offshoring of R\&D: looking abroad to improve innovation performance', Journal of International Business Studies, Vol. 42, No. 3, pp.345-361.

Nieto, M.J. and Santamaria, L. (2007) 'The importance of diverse collaborative networks for the novelty of product innovation', Technovation, Vol. 27, Nos. 6/7, pp.367-377.

Padula, G. (2008) 'Enhancing the innovation performance of firms by balancing cohesiveness and bridging ties', Long Range Planning, Vol. 41, No. 4, pp.395-419.

Parida, V., Westerberg, M. and Frishammar, J. (2012) 'Inbound open innovation activities in high-tech SMEs: the impact on innovation performance', Journal of Small Business Management, Vol. 50, No. 2, pp.283-309.

Phelps, C.C. (2010) 'A longitudinal study of the influence of alliance network structure and composition on firm exploratory innovation', Academy of Management Journal, Vol. 53, No. 4, pp.890-913.

Rothaermel, F.T. and Deeds, D.L. (2004) 'Exploration and exploitation alliances in biotechnology: a system of new product development', Strategic Management Journal, Vol. 25, No. 3, pp.201-221.

Salge, T.O., Bohné, T.M., Farchi, T. and Piening, E.P. (2012) 'Harnessing the value of open innovation: the moderating role of innovation management', International Journal of Innovation Management, Vol. 16, No. 3, pp.1-18.

Salman, N. and Saives, A.L. (2005) 'Indirect networks: an intangible resource for biotechnology innovation', $R \& D$ Management, Vol. 35, No. 2, pp.203-215.

Sampson, R. (2007) 'R\&D alliances and firm performance: the impact of technological diversity and alliance organization on innovation', Academy of Management Journal, Vol. 50, No. 2, pp.364-386.

Santamaria, L. and Surroca, J. (2011) 'Matching the goals and impacts of R\&D collaboration', European Management Review, Vol. 8, No. 2, pp.95-109.

Schilling, M. and Phelps, C. (2007) 'Interfirm collaboration networks and knowledge creation: the impact of large scale network structure on firm innovation', Management Science, Vol. 53, No. 7, pp.1113-1126. 
Sisodiya, S.R., Johnson, J.L. and Grégoire, Y. (2013) 'Inbound open innovation for enhanced performance: enablers and opportunities', Industrial Marketing Management, Vol. 42, No. 5, pp.836-849.

Soh, P-H. (2003) 'The role of networking alliances in information acquisition and its implication for new product performance', Journal of Business Venturing, Vol. 1, No. 8, pp.727-744.

Spithoven, A. (2013) 'Open innovation practices and innovative performances: an international comparative perspective', International Journal of Technology Management, Vol. 62, No. 1, pp.1-34.

Spithoven, A., Frantzen, D. and Clarysse, B. (2010) 'Heterogeneous firm-level effects of knowledge exchanges on product innovation: differences between dynamic and lagging product innovators', Journal of Production and Innovation Management, Vol. 27, No. 3, pp.362-381.

Suh, Y. and Kim, M.S. (2012) 'Effects of SME collaboration on R\&D in the service sector in open innovation', Innovation: Management, Policy \& Practice, Vol. 14, No. 2, pp.1124-1153.

Svetina, A.C. and Prodan, I. (2008) 'How internal and external sources of knowledge contribute to firms' innovation performance', Managing Global Transitions, Vol. 6, No. 3, pp.277-299.

Tomlinson, P.R. (2010) 'Co-operative ties and innovation: some new evidence for UK manufacturing', Research Policy, Vol. 39, No. 6, pp.762-775.

Tsai, K.H. (2009) 'Collaborative networks and product innovation performance: toward a contingency perspective', Research Policy, Vol. 38, No. 5, pp.765-778.

Tsai, K.H. and Chang, H.C. (2008) 'The contingent value of inward technology licensing on the performance of small high-technology firms', Emerging Markets Finance and Trade, Vol. 44, No. 4, pp.88-98.

Tsai, K.H. and Wang, J.C. (2007a) 'A longitudinal examination of performance of two ways on innovation in Taiwan: internal R\&D investment and external technology acquisition', International Journal of Technology Management, Vol. 39, Nos. 3/4, pp.235-247.

Tsai, K.H. and Wang, J.C. (2007b) 'Inward technology licensing and firm performance: a longitudinal study', R\&D Management, Vol. 37, No. 2, pp.151-160.

Tsai, K.H. and Wang, J.C. (2009) 'External technology sourcing and innovation performance in LMT sectors: an analysis based on the Taiwanese technological innovation survey', Research Policy, Vol. 38, No. 3, pp.518-526.

Tsai, K.H., Hsieh, M.H. and Hultink, E.J. (2011) 'External technology acquisition and product innovativeness: the moderating roles of R\&D investment and configurational context', Journal of Engineering and Technology Management, Vol. 28, No. 3, pp.184-200.

Un, C.A., Cazurra, A.C. and Asakawa, K. (2010) 'R\&D collaborations and product innovation', Journal of Product Innovation Management, Vol. 27, No. 5, pp.673-689.

Vanhaverbeke, W., Duysters, G. and Noorderhaven, N. (2002) 'External technology sourcing through alliances or acquisitions: an analysis of the application-specific integrated circuits industry', Organization Science, Vol. 13, No. 6, pp.714-733.

Vanhaverbeke, W., Gilsing, V., Beerkens, B. and Duysters, G. (2009) 'The role of alliance network redundancy in the creation of core and non-core technologies: a local action approach', Journal of Management Studies, Vol. 46, No. 2, pp.215-244.

Vega-Jurado, J., Gutierrez-Gracia, A. and Fernandez-de-Lucio, I. (2009) 'Does external knowledge sourcing matter for innovation? Evidence from the Spanish manufacturing industry', Industrial and Corporate Change, Vol. 18, No. 4, pp.637-670.

Wadhwa, A. and Kotha, S. (2006) 'Knowledge creation through external venturing: evidence from the telecommunications equipment manufacturing industry', Academy of Management Journal, Vol. 49, No. 4, pp.819-835.

Walker, R. (1995) Patents as Scientific and Technical Literature, Scarecrow Press, Metuchen, NJ.

Wang, Y., Zhou, Z. and Li-Ying, J. (2012) 'The impact of licensed-knowledge attributes on the innovation performance of licensee firms: evidence from the Chinese electronic industry', Journal of Technology Transfer, Vol. 38, No. 5, pp.699-715. 
Wu, Y.C., Lin, B.W. and Chen, C.J. (2013) 'How do internal openness and external openness affect innovation capabilities and firm performance?', IEEE Transactions on Engineering Management, Vol. 60, No. 4, pp.704-716.

Zeng, S.X., Xie, X.M. and Tam, C.M. (2010) 'Relationship between cooperation networks and innovation performance of SMEs', Technovation, Vol. 30, No. 3, pp.181-194.

Zhou, K.Z. and Li, B.C. (2012) 'How knowledge affects radical innovation: knowledge base, market knowledge acquisition, and internal knowledge sharing', Strategic Management Journal, Vol. 33, No. 9, pp.1090-1102. 